\title{
The 7-J Ranch Site (41HO4) in the Post Oak Savannah of East Texas, Houston County, Texas
}

Timothy K. Perttula

Heritage Research Center, Stephen F. Austin State University

Follow this and additional works at: https://scholarworks.sfasu.edu/ita

Part of the American Material Culture Commons, Archaeological Anthropology Commons, Environmental Studies Commons, Other American Studies Commons, Other Arts and Humanities Commons, Other History of Art, Architecture, and Archaeology Commons, and the United States History Commons

Tell us how this article helped you.

This Article is brought to you for free and open access by the Center for Regional Heritage Research at SFA ScholarWorks. It has been accepted for inclusion in Index of Texas Archaeology: Open Access Gray Literature from the Lone Star State by an authorized editor of SFA ScholarWorks. For more information, please contact cdsscholarworks@sfasu.edu. 
The 7-J Ranch Site (41HO4) in the Post Oak Savannah of East Texas, Houston County, Texas

\section{Creative Commons License}

\section{(c) (1) \&}

This work is licensed under a Creative Commons Attribution-NonCommercial 4.0 International License 


\title{
The 7-J Ranch Site (41HO4) in the Post Oak Savannah of East Texas, Houston County, Texas
}

\author{
Timothy K. Perttula
}

\section{Introduction}

The 7-J Ranch site (41HO4) is a multi-component Woodland period and Early Caddo period habitation site on a natural rise in the Trinity River floodplain in the Post Oak Savannah of East Texas (Figure 1). It is in an area of the middle reaches of the Trinity River where Woodland period sites (dating from ca. 500 B.C. to A.D. 800) are notably common on alluvial landforms, in particular Holocene Terrace-1 and alluvial rise landforms (Perttula 2015; Perttula et al. 2015).

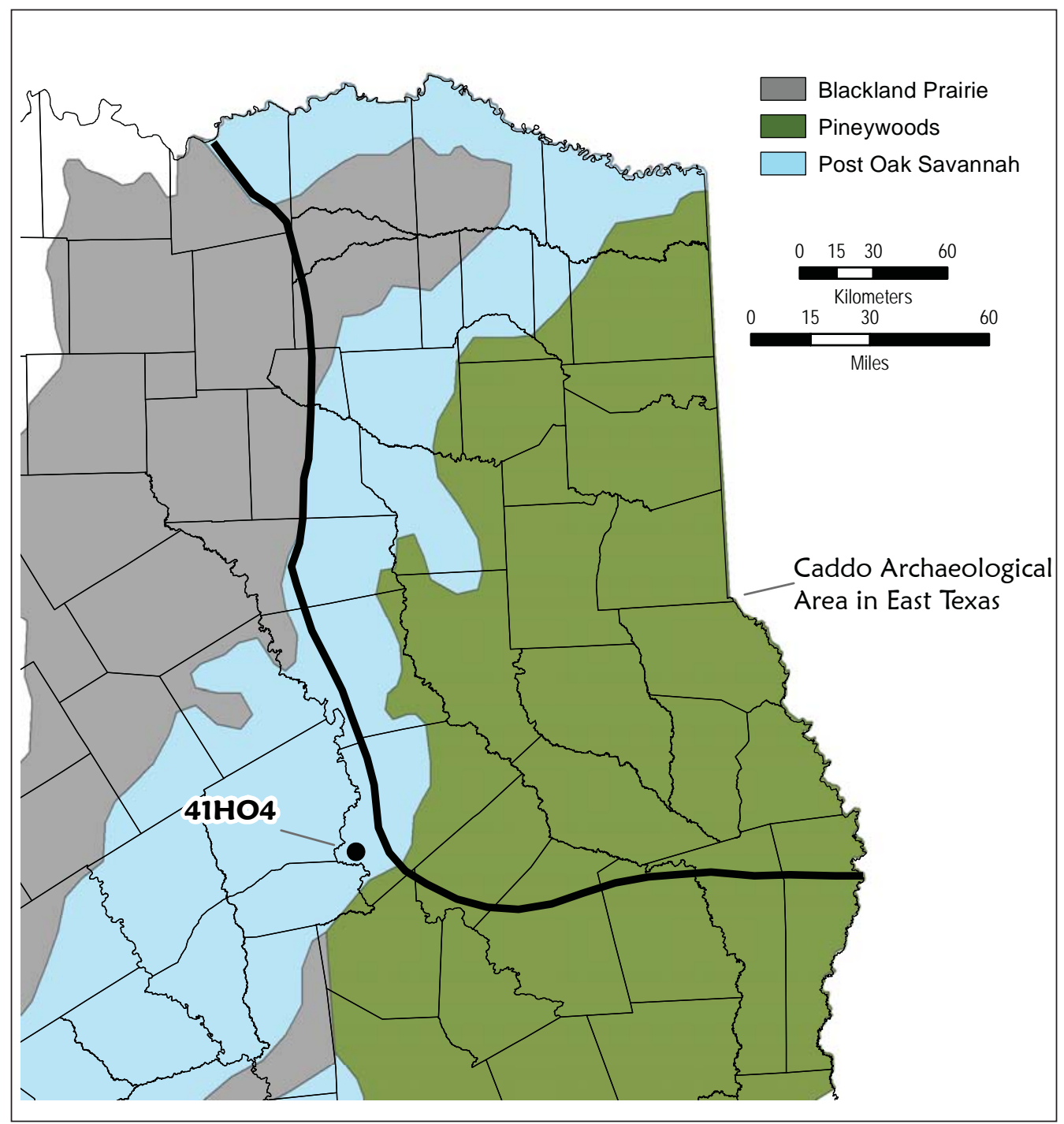

Figure 1. The location of the 7-J Ranch site (41HO4) in East Texas. 
The site appears to be a midden mound built up from the accumulations of habitation debris along the edge of the modern floodplain and the modern river channel. The midden mound is between 2-3 $\mathrm{m}$ in height and may cover as much as a $90 \times 45 \mathrm{~m}$ area. The midden soil has been described as a black sandy soil with abundant amounts of preserved organic remains.

The 7-J Ranch site has received no excavations since it was first recorded in the early 1960s, but several surface collections have been obtained from the site by University of Texas archaeologists in 1960, 1962, and 1977. These collections are curated at the Texas Archeological Research Laboratory at The University of Texas at Austin.

\section{Artifact Assemblage}

In addition to mussel shell fragments, burned animal bone $(n=2)$, unburned animal bone $(n=32)$, lithic debris, and burned clay pieces $(n=1)$, there are chipped stone tools and ceramic vessel sherds in the collections from the 7-J Ranch site. The chipped stone tools in the assemblage include a petrified wood Darl dart point, a petrified wood arrow point fragment, a Steiner arrow point made of a local red chert, and a petrified wood Alba arrow point.

There are two ceramic wares in the sherd assemblage from the site. The first ware is represented by sandy paste Goose Creek Plain, var. unspecified sherds (see Story 1990), common in Woodland period sites in the middle Trinity River basin (Perttula 2015), while the second ware consists of sherds from grog- and bone-tempered Early Caddo period (ca. A.D. 900-1200) ceramic vessels.

The various collections have 28 Goose Creek Plain, var. unspecified sherds. This includes two plain rims - probably from bowls or jars, 22 body sherds, and four base sherds.

The Early Caddo period ceramic sherds $(\mathrm{n}=12)$ include a horizontally incised rim from a grog-tempered vessel, probably Davis Incised (Suhm and Jelks 1962), a grog-tempered body sherd with rows of fingernail punctations, a plain grog-tempered rim, six plain grog-tempered body sherds, a grog-tempered base sherd, a plain bone-tempered rim sherd, and a plain bone-tempered body sherd. About 83 percent of the Early Caddo ceramic sherds are from grog-tempered vessels.

\section{Summary and Conclusions}

The midden mound in the floodplain of the Trinity River in Houston County, Texas, at the 7-J Ranch site appears to have accumulated between ca. A.D. 200 and A.D. 1200, in the Woodland and Early Caddo periods. Based on the artifact collections from the site, the most substantial occupation took place during Woodland

period times. Through time, beginning in the Woodland period, the Native American groups in this part of Texas became less mobile, as evidenced by the development of midden deposits on a number of habitation sites, and they also developed distinctive territories within which diverse settlement and subsistence patterns began to fully develop.

\section{Acknowledgments}

I appreciate the assistance provided by Marybeth Tomka in accessing the collections from the 7-J Ranch site. Sandy Hannum prepared Figure 1 in this article. 


\section{References Cited}

Perttula, T. K.

2015 Woodland Period Sites in the Middle Trinity River Basin, Houston and Madison Counties, Texas. CRHR Research Reports, Volume 1, Article 4. http://scholarworks.sfasu.edu/crhr/crhr_research reports/vol1/ iss $1 / 4$.

Perttula, T. K., B. Nelson, and S. W. Ahr

2015 Archeological Survey Investigations on the Eastham State Prison Farm and Ferguson Prison Unit, Houston, Madison, and Walker Counties, Texas. Report of Investigations No. 142. Archeological \& Environmental Consultants, LLC, Austin and Pittsburg.

Story, D. A.

1990 Cultural History of the Native Americans. In The Archeology and Bioarcheology of the Gulf Coastal Plain, by D. A. Story, J. A Guy, B. A. Burnett, M. D. Freeman, J. C. Rose, D. G. Steele, B. W. Olive, and K. J. Reinhard, pp. 163-366. Research Series No. 38. 2 Vols. Arkansas Archeological Survey, Fayetteville.

Suhm, D. A. and E. B. Jelks (editors)

1962 Handbook of Texas Archeology: Type Descriptions. Special Publication No. 1, Texas Archeological Society, and Bulletin No. 4, Texas Memorial Museum, Austin. Reprinted in 2009, Gustav's Library, Davenport, Iowa. 